\title{
MÄLESTUSI MEEKSI JAANIPÄEVAST
}

\author{
$\underline{\text { Heiki Valk }}$
}

\section{3}

Lähme Meeksi - homme on sääl jaanipäev. Vana, Setomaa oma. Lähme vaatama, mis sellest kõigest nüüdseks alles on jäänud. Varem ei ole sellel pühal käinud meist keegi. Reisiseltskonnaks on Ergo, Mari-Ann, Riina, Esta, Andres ja Margo.*1 Sõit viib Tartust keskpäevase rahvast täis kiirbussiga Võrru ja sealt väiksemaga edasi Vahtseliina teeotsa.

Luhamaa maanteelt kõnnime edasi jala. Pärast viibimist Vahtseliina linnusevaremetes algab kella poole seitsme paiku rännak sihtpunkti poole. Liigume mööda kõrvalteed, kus Meeksi ojal on oodatud väikese puusillakese asemel nõukogude aja pärandina betoonpaneelidest moodustis. Teeme paar kõrvalepõiget ühte mahajäetud taluvaresse ja teise, elavasse talusse, et kuulata maad jaanipäeva kohta.

Poole üheksa paiku oleme Meeksis, seto keeli Miikses. Kui külla jõuame, lõpetab osa rahvast veel kiiret heinatööd. Oleme päral, aga päev on veerenud juba madalasse ja on viimane aeg vaadata, kust leida öövarju. Üsna külasse tuleva teeotsa lähedal istub aias tule ümber seltskond mehi. Lähme ligi ja teeme juttu - et tulime Tartust siia jaanipäevale, ekstra selle pärast. Vähese aja möödudes olemegi lõkke äärde istuma kutsutud, kus saame osa sääl pakutavast. Ääri-veeri öömajast juttu tegemise peale näitab peremees kuurialust, kus maas mullused heinad - kui rahul oleme, võime siia jääda. Sinna end sisse seamegi.

Aja enne jaanitulele minekut veedame samas seltskonnas. On rahuline õhtu ja kiiret ei ole kellelgi. Vanim kohalolija, üle 70 aasta vanune naabertalu peremees kõneleb loo sellest, kuidas ta 15-18aastase poisina käinud jaaniööl koos isaga Vahtseliina lossivaremetes kulda otsimas. Unes näidatud, millise kivi alla varandus on peidetud, seda tulnud välja kaevama minna kesköösel. Kui aga õige kivi leitud ja kaevama hakatud, olnud meestel vanapaganad äkki seljas - nii ku kassiq! - ja hakanud küüntega kiskuma. Mehed visanud labidad käest ja vaadanud, kuidas koju saanud. Jutustaja kommentaar loo kohta on järgmine: Vanast ôks oll' noid vanapaganit. Noq om kõik kohaq nii tehnikat täüs, ôt tondil olõ-i inämb kohta, koh olla.

Majaperemees, umbes 50 -aastane mees on koos oma 18 -aastase pojaga pühadeks kohale sõitnud Tartust. Seal töötab ta mingi suurema tööstusettevõtte juhtkonnas. Kuuldes, et oleme tulnud jaanipäeva vaatama, on mees napisõnaline: Ma ei räägi sulle midagi! Küll sa homme ise näed ja saad aru!

Öö saabudes, umbes poole kaheteistkümne paiku, lähme koos võõrustajatega jaanitulele. Teel sinna möödume Meeksi oja kaldal olevast Jaanikivist. Kivi ümbrus on tühi ja vaikne, õhtuhämarus üle minemas ööpimeduseks. Jaanituli on kivist sajakonna meetri kaugusel - poolkaares põõsastega piiratud heinamaal võsa ja põllu vahel. Kui kohale jõuame, on tuli juba süüdatud. Lõkke ümber on ligi kolmkümmend inimest, peamiselt kohalik rahvas - nii nooremaid, keskealisi kui vanemaid. Täiskasvanute vahel liigub ka väiksemaid ja suuremaid lapsi; siin-seal käib ringi pudel.

Istume maha koos võõrustajatega, kellel kodust kaasa võetud mõned süldikausid. Kraamime lagedale ka omad leivad-konservid ja muud. Öö on vaikne ja poolpilves taevas kumab hallilt. Mingil ebamäärasel viisil annab end tunda ligi kilomeetri taga oleva Vene piiri lähedus. Teine riik juba. Joogid teevad seltskonna hooti lärmakaks. Lõkkest kaugemal tee ääres seisab paar autot. Neist 
ühes keeratakse täisvõimsusega mängima hoogne lindimuusika, mis moodustab märgatava dissonantsi öö ja atmosfääriga, aga kohalolijaid ei paista see häirivat. Siiski on tantsijaid vähe. Setu rahvariideid ja setu laulu ei ole.

Jaanitulel paistab eriti silma naabruses olevast vene külast Kuksinast pärit Sergei - umbes 50-60aastane mees. Sergei olevat sündinud mingis Petserimaa vene külas, vahepeal Viljandis töötanud ja nüüd kodukanti tagasi tulnud. Et Vene pool polevat tahtnud teda vastu võtta - see tähendaks kuuele või kaheksale lapsele lapsetoetuse maksmist - seadnud Sergei end sisse Kuksinasse. Mees on juba tugevasti purjus ja väga hoos. Küll heatahtlik, aga märkab meie tüdrukuid ja tahab neid tantsima rebida. Kui Sergeiga jutuks läheb, manitseb üks võõrustajatest, tagasihoidlik Haapsalu poiss, kes olusid tunneb, mind ettevaatusele: Sergei tagataskust paistab välja suur pussnuga, tera ülespidi. Mehe huvi õnnestub jookide abil siiski mujale pöörata. Öö läheb külmaks ja umbes kella kahe paiku suundume oma kuurialusesse öömajja, et järgmisel päeval vormis olla.

Hommikul kella poole viie paiku tuleb kuuri alla peremees, kes ütleb, et tahab minuga rääkida. Tõusen üles ja lähme kööki. Hommik on karge ja jahe, päev pilvede vahelt ülesse tõusmas. Korjame peenralt sibulaid ja rediseid ning võtame vao vahelt esimesi kartuleid. Puhastame need ära, hakime sibulad ja redised ning segame hapukoorega. Peremees pole öösel maganud ja räägib vähe. Jutu sisu on sama mis õhtulgi: «Ma ei räägi sulle midagi, küll sa näed ise!» Mehel on siiski väga teravalt hinge peal mingi Tallinna ajakirjaniku kirjatöö, kus setudele heidetakse ette lugupidamatust surnute vastu: nad joovat pühade ajal ennast kalmistul täis ja käivat haudade vahel laaberdamas!

Poole kaheksa paiku teen esimese käigu Jaanikivi jurde. Küla on vaikne ja näib magavat, inimesi pole kusagil. Rohi on kastemärg ja kivi juures ei anna veel miski märku siin peagi algavast pühast.

Seltskond ärkab kella kaheksa - poole üheksa paiku. Kõik kutsutakse tuppa, kus on valge linaga kaetud söögilaud. Koos sööme jaanipäeva hommikueinet, mis koosneb kartulitest, varahommikusest salatist ja keldrist toodud, peremehe enda keedetud süldist. Hommikusöök koos nõude pesemisega kestab ligi üheksani. Siis tõttame lahkuma, et olla koos ja omaette Meeksi Jaanipäevas.

Liigume rada mööda surnuaiale ja seame end istuma selle servale mäenõlvaku pääle, et vaadata all oja ääres Jaanikivi juures toimuvat. Nüüd on seal alanud liikumine. Aeg-ajalt läheb värviliste rätikutega vanemaid, enamasti $60-80$-aastasi naisi üksi või paarikolme kaupa alla oja äärde. Minnakse üle purde kivile ja tullakse säält varsti tagasi. Kiriku juurde koguneb rahvast, autodega ja jalgsi. Teenistus algab kell kümme, kuid rahva juurdevool kalmistule jätkub ka selle ajal. Kiriku ees ja surnuaial on kogu aeg

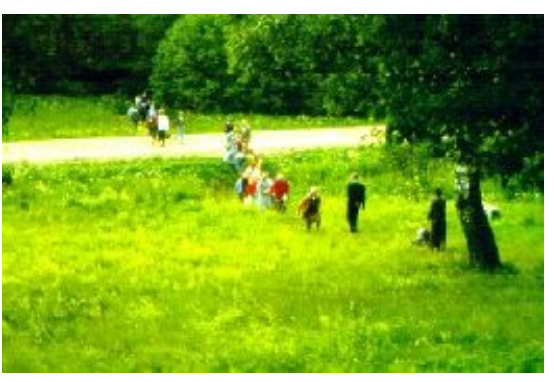
inimesi, kes omavahel juttu ajavad. Meie seltsiv võõrustaja on kadunud kogu hommikupooliku.

Kivi juurde minna ei ole algul tahtmist või julgust: mõte, et võiksime kõrvalistena minna püha kivi ja sääl toimuva ligi, on esmalt liialt võõristav. Ka pole teada, milline võiks olla inimeste suhtumine mujalt tulnud võõrastesse. Niimoodi siis surnuaia veerel istumegi. Tasapisi suureneb all oja juures käijate vool. Nüüd viibib seal juba pidevalt kümmekond inimest ning tipphetkedel ulatub hulk kolm-neljakümneni. Palju on ka nooremat rahvast - keskealisi ja väikeste lastega peresid. Arvestades laste ja noorte hulka kivil käimine veel nii pea ei kao.

Olukord on sedavõrd muutunud, et hakkame meiegi ühe- või paarikaupa käima kivi juures. Päris kivilkäijaid, peamiselt vanemaid naisi, ei paista meie kohalolek häirivat. Vastu kivi pannakse käsi või kummardatakse põlvili kivi peal olles selle vastu otsaesine. Kivilt lahkudes jäetakse sinna oma annid, enamasti raha, mis tihti poetatakse kiviprakku. Meelde jääb suurivaevu nõlva pidi alla kivi 
juurde tulev vana naine ja tema omaette tasased sõnad: Oh helde Taevaisake! Oh helde Taevaisake! Kuu aega hiljem, augustis, satun Sesniku külas juhuslikult tema külaliseks. Naine on olnud tõsiselt hädas oma paistes jalgadega, mille jaoks on ka varem kivilt abi saanud. Ta peab veel praegugi kõiki paaste ja palub pühaseid. Rahvas tuleb ja läheb. Püha kivi juures on roostetanud ja ripakil valge emailtahvel, mis tutvustab seda kui riikliku kaitse all olevat arheoloogiamälestist. Kivilkäijate jaoks tähise olemasolu või puudumine korda ei lähe.

Kivi juurde tuleb ka üksikuid venelasi, kelle riietus kuidagi tumedam ja askeetlikum kui setude oma. Silma hakkab üks kõhn väga tõsise näo ja kõvasti ümber pea seotud hallikassinise rätikuga 1415-aastane Venemaa külatüdruk. Selgub, et tulijaid on isegi Ukrainast. Kivi juures, kus nüüd on ka nooremat rahvast, toimetab korraga enamasti vaid üks inimene. Teised seisavad oja kivipoolsel kaldal, oodates oma järjekorda. Järjekorra teise järgu moodustavad oja kirikupoolsel kaldal olijad. Kivi juures, oja ja nõlva vahel olev plats on üsna väike ning seab sinna mahtuva seltskonna suurusele piirid.

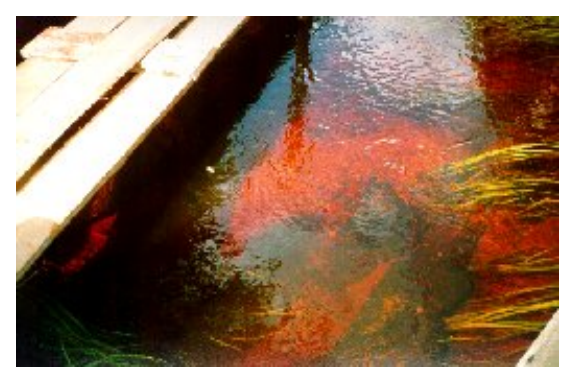

Kivil käimisega liitub lahutamatult selle külje all voolavast ojast vee võtmine ja sinna müntide heitmine. Võetud veega pestakse silmi ja visatakse siis ojasse metallraha. Osa müntidest vajub kohe peenesse põhjaliiva, teised jäävad oja põhja lebama. Vahel pannakse vett kaasaviimiseks ka pudelisse. Küsimise peale saan teada, et imeline ravitoime on Meeksi ojal vaid kord aastas jaanipäeval. Kui kivil käijate enamuse moodustavad vanemad naised, siis rahaviskajate seltskond on märksa kirevam. Ojal käiakse perede kaupa, kaasas ka väikesed lapsed. Jääb mulje, et kiviga otsib kontakti vaid osa allatulnutest, enamus piirdub ojal silmade pesemise ja müntide viskamise või niisama ringivaatamisega. Meeste suhtumine toimuvasse on üldiselt märksa vähem tõsine kui naistel. Ilmne, et paljude jaoks pole raha viskamisel enam sisulist tähendust ja seda võetakse kui poolnaljaks olevat kombetäitmist. Siiski ei paista kusagilt halvustavat või üleolevat suhtumist tõsimeeli kivil käijate ja abiotsijate vastu. Liikumine kivi juurde on kõige suurem ligikaudu kella üheteistkümne ja poole ühe vahel, siis hakkab käijaid tasapisi vähemaks jääma.

Päeva tähtsust ja pidulikkust rõhutab inimeste riietus. Kuigi linnast tulnu pilgu läbi tihti lootusetult ajast läinud - leidub ka krimpleeni ja muid paarikümne aasta eest moega kaasas käinud riideesemeid -, on kohalolijate rõivastus silmapaistvalt pidulik. Rahvas on selgelt pühaderõivas. Vanemad mehed on ülikondades, nooremad särgi või seda katva jaki väel. Vanadel naistel on peas ilusad, tihti värvikad rätikud. Lapsed on riides värvikirevalt, ette tuleb ka mikihiiri ja donaldparte. Kogu inimhulga kohta leidub vaid üksikuid teksades ja suvistes argirõivastes olijaid. Üldisel pidulikul foonil moodustab erandi vaid meie reisuseltskonna lihtne suvine rännurõivastus, mis selle kandjaid end mõneti ebamugavalt tundma paneb.

ÜIeval kirikaias vanade kaskede all valitseb rahvahulgale vaatamata rahu. Kalmistul, kivi ja oja ümbruses on võimalik kogeda oleva aja pühadust. Inimesed seisavad, jalutavad või istuvad, vanemad ka hauapinkidel. Aetakse vaikselt juttu ja teretatakse tuttavaid. Pidevalt toimub rahva liikumine kirikusse ja sealt välja - väike kirik ei suudagi korraga mahutada kohalolevat inimhulka. Rahvast tuleb surnuaiale pidevalt juurde. Valitseb mingi vaoshoitud ootus. Kulminatsioon ei ole veel saabunud.

Umbes poole kahe ajal väljub rahvas kirikust, sulades ristikäiguna üheks vooluks kiriku ees ja ümbruses ootava hulgaga. Oodatud aeg on käes, kõikjal tekib elevus ja liikumine. Kantakse kirikulippe ja ikoone, preester piserdab rahvast pühitsetud veega. Pühasid lippusid ja pilte hoidvad vanemad 
mehed, ühtviisi nii setod kui venelased, on ülikondades, vahel isegi lipsuga. Kandjate maamehenäod on tõsised ja pühalikud. Kirikulippude kandjate seas on ka Sergei, kellega öösel kohtusime hoopis teises olemisviisis.

Ristikäigu lõppedes on kogu õhustik muutunud. Tõsidus on kadunud, alanud on teine aeg ja teistsugune elevus. Rahvamass - kokku vast 500-600 inimest - valgub kiriku juurest laiali üle kalmistu. Pinkidele ja kalmudel olevatele laudadele ilmuvad valged linad, võileivad, tordid, kringlid, kommid, küpsised ja muud küpsetised. Ei puudu ka viina- ja veinipudelid, mida ei hakka siiski kusagil silma korraga rohkem kui üks. Kalmistul olev rahvas on jagunenud hauaplatsidele seltskondadesse, mida ehk võiks nimetada ka haudkondadeks. Istutakse perede või suguvõsade kaupa, süüakse ja aetakse juttu.

Rahvahulgas kohtume taas eilse võõrustajaga, kes kutsub meid osa saama omaste haudadele kaetud söögilauast. See hauale kaetud pühadelaud on tõsiseks kontrastiks tänasele lihtsale hommikueinele. Laual on hõrgutav shokolaadikringel, küpsiseid ja mitmesuguseid komme. Ühe hauaplaadi juures maas märkan sinna asetatud tühje tolmunud ja vihmast liivaseks pekstud viinapitse. Perepoeg ütleb, et varem olevat viina ka haudadele valatud, aga nüüd hakkavat see komme ära kaduma. Püüan toimuvat fotole jäädvustada. Õhtuse lõkke ääres olnud külapoisid kutsuvad ka ennast pildistama.

Ligi poole tunni möödudes pärast söömaaja algust suureneb kalmistul liikumine. Nüüd hakatakse vastastikku üksteise juures külas käima. Küllakutsetele vastab ka meie võõrustaja, liikudes ringi erinevate hauaplatside vahel. Mäletan momenti, kus mees, keda on kutsutud korraga kahte kohta, on sunnitud ühe käikudest seetõttu edasi lükkama. See olukord teeb ta silmanähtavalt murelikuks minemata jätmist või sellega viivitamist võib kutsuja võtta kui solvamist. Vesteldakse palju ja elavalt. Hommikupoolikul surnuaial valitsenud pühalikkus ja tõsine atmosfäär on haihtunud inimesed söövad, suhtlevad ja on rõõmsad. Kivi juures ei ole nüüd enam kedagi - koos teenistusega on ka kivil käimine lõppenud.

Perekalmul ajan taas juttu võõrustajast peremehega. Tunnen huvi, kas rahvast on tänavu sama palju kui tavaliselt. Selgub, et inimesi olevat märksa vähem kui muidu - Vene piir on esimest aastat kinni, mistõttu sealtpoolt tulijaid peaaegu ei olegi. Ka olevat piiri kinnioleku tõttu hobuseid vähem kui tavaliselt - surnuaia taga sööb neid seekord vaid kaks. Küsin, kunas kadusid kivi juurest kerjused, keda seal veel 1930. aastatel oli olnud hulgana ande vastu võtmas. Kerjuste tulek Petserist olevat ära jäänud kohe Nõukogude aja alguses. Kui tunnen huvi, mis saab kivile viidud asjadest, on vastuseks, et sinna pandut ei puutu keegi. Et keegi kohalikest inimestest kivilt midagi võtaks, on absoluutselt välistatud - asjad kaovad kivilt ise ära! Küsimusele, kas Jaanikivi ja jaanipäeva tõttu on Meeksis ka midagi teistmoodi kui teistes külades, on vastuseks, et Meeksis on alati iseäralik rahu siin ei juhtu õnnetusi. Sõjad ja hädad, mis mujal palju kannatusi toovad, on Meeksist ikka mööda läinud - nagu mingi kaitse on küla peal. Nii ei saanud küla purustada viimase sõja ajal; ka ei küüditatud siit inimesi ära. Kõik sõjaeelsed talud on praegugi alles ja asustatud kohalike elanikega. Kuigi lähedal on piir, on ka praegu siin vaikne - isegi salakaubavedu ei käi siitkaudu, vaid mõni kilomeeter eemalt.

Umbes tunni möödudes tõuseb taevasse tume äikesepilv. Inimesed korjavad kiiruga kokku toidud ja laudlinad. Rahvahulk surnuaial hakkab kiiresti hõrenema ja autod lahkuvad. Lahkume meiegi, et jõuda Võrru minevale bussile. Teel möödume Jaanikivist ja teeme sinna viimase külaskäigu. Kivil on paar rätikut, sokid, hulk metallraha - peamiselt Eesti sente, kuid ka üksikuid Vene metallrublasid -, mõned väiksemad paberrahad, kustunud küünlajupp ning kaks kimpu lilli. Kivi kõrval rohu sees on veidike lambavilla.

Teel möödume vanast, kõrge katusega maakivilaudast, mille seinasse kunagi müüriti lõhutud Jaanikivi tükk. Lahkume mööda maanteed, kus kerge vihmahoog on tolmu kinni löönud. Peagi tuleb buss. See oli Jaanipäev Meeksis, anno Domini 1993. 


\section{Jaanilaupäev ja jaanipäev 1996}

Lahkun Tartust nagu ikka 7.30 bussiga. Sõidan üksi. Võrus koperdan linna pidi, ostan süüa. Bussijaamas selgub, et ühtegi bussi Räpina teed pidi minemas pole. Kõnnin linna piirile ja lähen häälega. Kohe esimene auto viib mu Otsale, poole maa pääle. Siis järgmisega - tuleb üsna varsti - saangi Andrikovva. Uurin homseid Meeksi saamise võimalusi ja ütlen, et olen teel Navikesse heinale - nii nagu sääl kahe nädala eest eelmisest käimisest tulenes.

Lähen mööda teed, ilm on ilus. Teen enne Naviket (st Navige küla) peatuse - sääl, kus on rukis ja rukkililled. Siis astun edasi. Kuusiku Olli, keda kahe nädala eest kohtasime, küsibki: Noh, kas tulid heina tegama? Ütlen, et tulin jah ja et olen olemas õhtuni. Et nüüd ei ole kiire. Naine küsib, et kas saab minuga linna kohtukutse saata - et ootab lapsi, aga need ei tule. Sellised on tema naljad - jutt täitsa tõsine, aga pärast käib silmadest, mis kurvad nagu Alaveere Ollil Võmmorskis, läbi nukker naerukaar. Kutsub mind sisse. Eeskojas istub tooli pääl vana peremees Semmen, väga hea näoga, halli habeme ja kurbade heade silmadega. Pärast selgub, et on 83 aastane. Vaatab ja ei ütle midagi. Mina ütlen, et tulin heina tegema. Semmen vaatab mulle rõõmsa näoga otsa ja noogutab. Perenaine kutsub kööki, pakub piima ja keedukala. Siis lähme põllule. Hein on osalt vaaludes, osalt väikestes kuhjades. Tõmbame need laiali, et päikese ja tuulega ära kuivaks. Üksteise järel tulevad kaks autot kaks poega Võrust, üks oma naise ja tütrega, nii et heinalisi on küll. Oleme koos heinamaal ja lükkame ruttu heina laiali. Vanem poeg, umbes 50-ne, küsib, kes olen. Et kas folklorist. Ütlen, et midagi sinnapoole jah. Siis pärib, et kas tulid Pekost küsima? Et kui seda küsid, siis on kohe vastuseks "Ei-ei! Ei tea, ei tea!" Et see oli selline usk, mida pidi salajas hoidma. Ei tea, kas mõtles ta oma isa? Tema ju ainuke vana kohalik külainimene. Või teisi vanu - neid, keda enam ei ole ja kelle käest ka varem Peko kohta päritud.

Hein saab peagi pööratud, teha pole nagu midagi. Tuul on väga kõva ja kuivatab hästi. Olli kutsub mind tuppa - et ajame nüüd juttu. Lindistangi, aga jutt on kuidagi kuiv ja kinnine, kuigi jutustaja rääkida pingutab, et mulle häädmeelt teha. Kui küsin puugist, hakkab naine ise rääkima Pekost. Ei räägi aga eriti midagi. Siiski saan teada, et naabertalu peremees oli teda viimasena pidanud aiasaiba otsa pannu ja sis palunu. Kui minidisk kinni saab, tunneb naine silmaga nähtavat kergendust, jutt ja olek on kohe vabam.

Et heinaga midagi teha ei ole ja maja oma rahvast täis, otsustan käia ära Ignasel. Naine soovitab minna Laine Kati juurde - ta olla lahke ja jutukas. Soovitab öelda, et Kuusiku Olli saatis. Lähen. Esimese põike teen kõrvale tallu. Et suund on see, kuhu Olli viimsest Peko pidajast rääkides osutas, astun sisse. Teeotsa pidi on talu õue nii viiskümmend meetrit. Peaaegu kinnine õu on soe ja päiksega, rohi niitmata, kõik on maha jäetud. Lauda õlgkatus on sisse langenud, kõik on lagunev ja vaikne. Lauda vastas on väike

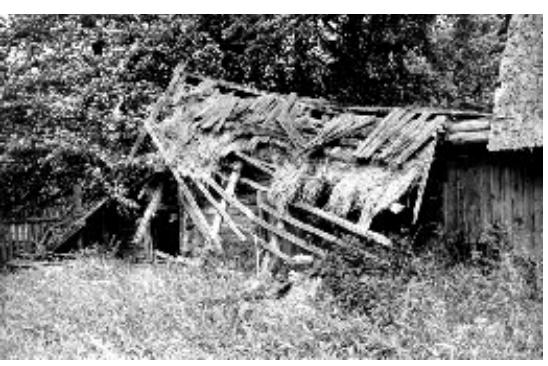
maja - vanamoodne seto tare: ainult eeskoda ja suurem palkseintega ruum, väga madal. Selliseid ümberehitamata maju on alles jäänud väga vähe. Tare sisustus on enamasti kadunud. Ümber seinte jooksevad vaid uued valged laudriiulid, mis näevad välja nagu vanad. Eeskojas on vanu puunõusid, säälhulgas ka meetri kõrgune tüvest õonestatud uhmer. Talu hooned on maha jäetud, aga mitte veel surnud. Seintel ripub hobuseriistu. Veel üks asi: ustel on väga palju musti riste - söega tehtud. Ei ole kusagil näinud nii palju riste kui selles mahajäetud talus.

Elumaja on uuema olemisega, astun ka sinna sisse. Kui ukse lahti teen, üllatun: põrandal on vili! Palju kollast kuiva vilja, väikeste loomade jäljed selle peal. Umbes meetri kõrgusel jooksevad üle elutoa parred, kust ripuvad alla vanad viljakotid. Ukse vastas on suur lesoga ahi. Pääle peremehe surma on seda maja kasutatud vilja kuivatamiseks. Katsun, et vilja sisse oma jälgi ei jätaks, ja 
vaatan tahapoole. Vili on ka teistes tubades. Kuiv ja kollane, põrandal maas. Maja sisustusest muud õieti alles polegi. Tagaruumis, eeskojast tuppa tulles on ka maja sees uksepiida kohale rist tõmmatud. Taandun eesukse kaudu välja. Siis, ees hääd kätt nurgas, näen risti üle toanurga tõmmatud raampuid. Kas pühasenurk? Lähen pimedas ligemale - ongi. Vana pühaserätt on puude kohal, ripub seinalt alla. Katsun seda ja lähen välja. Olen veel veidi aega õues, lasen silma poollooja. Tead ikka ei ole. Kui ta peaks tulema ja kuulma, et Ignasele läksin, tuleb ta siit läbi. Siit ei saa mööda minna. Päris magama siiski ei jää, olen poolunes. Siis tõusen ja lähen edasi.

Ignasele on vaid mõnisada meetrit. Esimesed talud on jõudsasti uut ehitanud, on kaasaegseid ehitusmaterjale ja muud, mis ei tõmba. Laine Kati maja on kolmas - nii nagu Olli õpetas. Maja juures sõidab rattaga väike tüdruk. Küsin tema käest, kas Laine Kati elab siin. Elab jah! Lähen sisse. Katil on ka nooremat rahvast abiks, need sätivad ühte rõugukest. Teretan Katit ja ütlen, et tunnen huvi vanade asjade vastu. Et tulin küsima seda, mida ei küsita ja millest ei räägita. Et tunnen huvi Peko vastu. Kati polegi küsimusest üllatunud, kutsub tare ette pingile istuma ja on lahkelt nõus juttu ajama. See teema pole tema jaoks mingi tabu - räägiks meelsasti, aga ei tea - kuigi on 73 aastane ja oma küla kõige vanem kohalik inimene. Ütleb mitu korda, et räägib kõike, mida ta teab, ja ma ka usun teda. Kuulen, et viimased Peko teenistused olid naabertalus, Otsa talu rehes. See rehi põles rehepeksu ajal sädemest maha kolhoosiaja alguses, paar aastat pääle küüditamist. Talus elasid kaks venda - Piitre ja Nikit, nende ema nimi oli Maarja. Kui Piitre Ignase Otsalt ära läks, Navikele - see oli juba Eesti ajal - võttis ta Peko sinna kaasa. Rahvas räägib, et Piitre olla Peko lõpuks ära müünud: Piitre müi maahha, ta sai pall'o raha, kõnõldas. Küsisin, kas Piitre oli ka kuidagi teistmoodi inimene, et kas pidas rohkem vanu kombeid ka või? - Ei, es olõ, tavalinõ inemine oll'. Piitre surnud alles hiljuti. Ollilt kuulen hiljem, et 1980. aastal. Peko kohta Kati muud kõnelda ei tea. Tema oli laps ja lastele neist asjadest ei räägitud: Ma ka tiiä-i. Latsilõ õs kõnõlda-as! Pärin, kas külarahvas viimaste Peko pidajate peale viltu ka vaatas või seda halvaks pidas? Ei, seda pole küll olnud: Ega ta ós olõ halv asi. Kas Peko pidajad ka kirikus käisid? - Käisid ikka, Piitregi oli suur kirikumees ja koguduses mingi asjamees, teenistuse ajal ikka käis kirikus ringi ja õiendas midagi. Küsin, kas Kati käest ka varem keegi Peko kohta küsinud on. Selgub, et ei ole. Et kui küsimas käidi, siis vanemate inimeste käest, tema on liiga noor. Ei tea Kati rääkida ka kuju välimuse kohta - vist olevat vahast olnud. Küsin Katilt ka veidi muid asju. Matustest kuulen, et surnule pandi kaasa vahel viinapudel neile, kes seda armastasid. Ja viht pää alla - mitte surnupesuviht, vaid muu. Vihaga siinkandis surnut ei pestudki, hoopis savikausist veega. Ja kirstu on pandud ka nõela - nõgõl panti mõnõlo - õt "sääl" tarvis parandaq. Raha pandi surnule rindu pääle. Pärast võeti ära ja osteti selle eest küünlad, mis pandi kirikus ümber kirstu põlema. Ja küünal ning taskurätt pandi kaasa. Seebi või söögi panekust pole Kati kuulnud. Küll räägib ta aga kääpä pääl söömisest. Kõige suurem söömine on paasapääva ja raadovitsa, st lihavõtte paiku. Kui küsin, et kas surnule kääpasse ka sööki antakse, ütleb Kati: Matusõ ajal mõnõq valavaq risti mano. - Õt tälle kaq. Surnu valvamine olnud vanasti väga tähtis, valvatud vahetustega. Midagi söödi ka valvamise juures, biskviiti või sarnast. Miks surnut valvati, seda Kati öelda ei oska. Jutu sees lipsab läbi Maa sõna Eesti tähenduses. Vanahalva lugusid Kati ei tea - neid kõneldi varem. Essütajaid Ignase kandis ka ei olevat - jäävad rohkem Obinitsa poole. Ustele ristisid tehtud siin küll, aga enam ei ole meeles, mis öösel: Kas vana-aasta vai? Inne hummogut tetti.

Üks liblikas on Kati jala pääl, mispeale teen juttu hingeliblikast. Kati tükib kohe liblikale äigama, see pääseb õnneks minema. Hingelip'kas kõnõldi jah. Ta om sääne hall. Noq ütlevaq "koi", vanast üüldi "hingelip'kas". Ma ka tiiä-i. See ma ka tiï̈-i ongi üks ütlemisi, mis Kati olemisest alles jääb. On ikkagi juba uuema aja inimene ja ennast selgesti selleks ka peab. Oma elu üle ta ei kurda pension on üle tuhande krooni ja sellega elab ilusti ära, lisaks oma majapidamine. Häda on aga, et lapsed on ära ja kõik maa seisab söötis - varem oli maa väga hinnas. Ka rikastes taludes olid lapsed Iõssi peal - piimakoor viidi müüki, et maad saaks osta. Siit külast oli Eesti ajal mitu peret välja 
rännanud - ostnud kohad Mulgimaale ja mujale Eestisse, kus maad rohkem. Üldiselt pole Kati aga kurva olemisega. Juttu tuleb ka maailma hädadest üldse. Küsin, kas ja mida siin ilmaotsast kõneldud on. Siis räägib, et samast külast suri veebruaris üks väga vana inimene, kes kõike teadis: ilmaotsast ja kindlasti ka Pekost. Ja et Maailmasõda on tulekul. Aga tema on surnud. Tema olevat rääkinud, et enne ilmaotsa tulekut kaob vesi ära. Et seda saab siis ainult Pihkvast: üts punase pääga naastõrahvas and. Rääkis ka, et siis otsitakse üksteist jälgipidi taga: Inemiseq kaovaq ar; jälgi pite läät. Kui küsin luba lindistamiseks ja teen ettepaneku tarre minna - kontakt on piisavalt hää ja jutu algus lahti räägitud - on Kati resoluutne. Lindistamist ei tule. Kati mainib veel oma halba kuulmist. Ütleb, et see on siinkandis üldine häda, et vanadel läheb kuulmine ära. Näiteid on minul omagi tuttavate seast küllaga: Kuusiku Olli ja Semmen, vana Mehilane ja Haaviku Ode. Ei tea, kas sugulusest tulenev asi.

Siis näitab Kati Otsa talu rehe aset. Selle asemele on ehitatud puukuur. Pole mingit välist märki kunagisest Peko teenistuste paigast - ainult mäluside. Kui küsin, kellega siin külas võiks veel rääkida, soovitab Kati minna naaberkülasse - kõige viimane talu enne metsa - ja saadab mu teeotsani.

Kõnnin mööda ühest talust, mis on täiesti varemetes. Suur kõrvalhoone on jäänud olematult hõredaks. Läbi varemete paistavad vana saan ja viljapeksumasin - rehealune vist. Samas ongi vana rehetoa palksein, veel püsti. Lähen varemeist edasi, istun veidi puu all ja söön. Siis edasi, juhatatud tallu.

Lähen hoovi. Koer magab ukse kõrval, siis ärkab ja hakkab haukuma. Astun ukse taha ja koputan. Kui ukse paotan, tuleb vastu umbes 50 -aastane naine. Olen sattunud just ebasobival hetkel. Naine on algul selgelt umbusaldav ja küsib, mida mul vaja on. Ütlen jälle otse - et tahan teada asja, millest ei küsita ja millest ei räägita, et tahan teada Pekost. Hoian pidevat silmsidet, tema hoiab vastu. Pilguside püsib kogu jutu ajal. Naine räägib algul, et ta ei tea midagi, et tema ei ole selle põlvkonna inimene. Räägib kirjakeelt. Siis ütleb, et Peko palvusele mindi pärast sauna. Aegapidi tuleb muidki detaile. Selgub, et Peko teenistustel käis tema vanaema. Et minekuks pani vanaema selga rahvariided, väga ilusad riided. Küsin, kas suur sõlg pidi olema. Seda ei tea, aga põll pidi kindlasti olema ees - viimane täpsustus ei tule küsimise peale, vaid iseenesest - ja need riidelindid olid seotud ümber pää. Selgub, et vanaema ei olegi kohalik, vaid toodud siia naiseks Petseri tagant Potalova külast. Vanaisa, kes siitküla inimene, ei olevat aga Peko teenistustel käinud. Oma vanaema naine ise näinud ei ole - kõik räägitu on ema juttude järgi meeles. Siis meenub veel, et söök pidi kaasas olema: see oli rätiku sees, mille neli nurka kompsuks kokku seoti. Järeldab-tuletab, et ju see siis kausiga pidi olema - muidu ju niimoodi ei viida. Hoian silmsidet ja naine püüab kõigest väest oma mälu läbi otsida. Siiski ei ole sääl eriti palju ja nii räägib ta üle ühtesid ja samu asju. Algne pinge ja võõristus on peagi kadunud. Küsib, et kuidas koer mind läbi laskis - muidu ta ju kange võõraid haukuma. Siis aga tükin ise minekule - muid asju küsima ei kipu. Kell on juba nii kaugel, et võiks olla aeg heina kokku panema hakata. Lähengi tagasi.

Navikes ongi teised juba heina vedamas. Olli kutsub mu ikka kõigepealt tuppa, pakub süüa. Siis lähen põllule järele. Paneme kuiva heina kokku ja veame kuuri. On meeletult kõva tuul, aga soe. Ideaalne heinailm. Ainult tuul tahab heina ja ka traktoripealset kuhja minema kanda, nii et seda tuleb kinni hoida. Tasapisi kisub pilve, lõuna poolt. Saame valmis just veidi enne vihma. Juttu tuleb sellest, et vihm ei lase õhtul vist tuld teha. Pojad ei saa aru, miks tuld peaks tegema. Siis alles jõuab pärale, et vana jaanipäev ju tulekul. Imestavad, et kui ema kirjutas, miks ta siis kirjutas ainult heinategemisest ja miks pühadest juttu ei olnud. Kuidagi jäi tunne, et oli nagu väike nöökamisi etteheide emale: laseb neil pühade ajal tööd teha ja seda ei ütlegi, et pühad on.

Siis peseme kausis maha suure heinatolmu ja lähme lauda. Söögiks on pannkoogid maasikamoosiga, kollased ja hästi palju. Ja keedukala ja värske piim. Ka leib ja omatehtud soolavõi. Sööme ja 
nüüd sätivad lapsed minekule. Pakuvad ennast mindki ära viima autoga naaberkülasse, aga saan sellest siiski ära ütelda nii, et nad ei pahanda - tahan veel vanadega juttu ajada.

Jutuks tuleb, et mehed käisid saunas alati enne naisi. Ka oma pere inimesed ei käinud koos. Varem olnud Navikel külasaun, nii et taludel oma saunu nagu väga ei olnudki. Üldse elati väga ühist elu. Küsin, miks mehed enne käisid. Olli ei tea täpselt. Ütleb, et mehed on kõvemad ja võtavad selle karmu ära, mis pääle kütmist sauna jääb. Olli räg̈gib veel elust-olust. Korraks astub tagumise eesriide tagant ettetuppa vana Semmen. Ütleb: Sergä küläl oll' mõisa ots ja voolja ots. Olli ei saa aru, tal on halb kuulmine. Semmen ütleb sedasama uuesti ja läheb eesriide taha tagasi. Tema elu kuigi kehaliselt veel selles ilmas - käib vist juba suuresti teisel pool. Suurema osa ajast Semmen ainult magab. Olli jutustab maast ja ilmast poole kümneni, ei lase mul jutuotsa võtta, et end minema sättida. Mingis seoses - rääkides oma põlvkonnast ja võrreldes seda "vanadega" on ta juba heinatöö ajal öelnud: Mi olõmi jo tõõsõ ao seeh kasunu. Kui kellast juttu teen, tuleb talle lehm meelde: see ju lüpsmata! Nüüd on Ollil kiire ja minagi olen minekul.

$*$

$*$

$*$

Andrikovas ootab Aare Meelist, kes tulebki poole kaheteistkümne ajal koos Ahtoga.르 Kuulen, et nad neljakesi on kõik Setomaa Vene poole pealt, st Venemaalt tagasi, ka Tuule, Merike ja Anzori*3 - ja et teised on Meelise juures Lillel. Lähen ka ööseks sinna. Tee pääl on üks sõiduauto kraavi sõitnud, naine roolis on päris hädas. Meelise auto ja meie jõust jääb väheks. Tuleb uuesti abi järele minna.

Siis Lille metsatalu Piusa orus. On väga hää näha Tuulet ja Merikest. Meelisel on olnud kolimine ja siin on muidki tema sõpru-tuttavaid. Anzori on nende seas. Üks poiss on põrandal maas ja Anzoor õiendab midagi pendliga. Oleme Tuule ja Merikesega tagatoas, räägime muljeid. Pärast käime veel metsa vahel hommikuvalgel. Üle põlendiku, kus Valgna Vasjol 5 hektarit metsa mullu maha põles.

Meeksi saame Tuule ja Merikesega hommikul umbes pool üksteist. Algul kirikusse, siis kivile. Kivi juures on halb üllatus: oja on ära kuivanud, ei ole piiskagi vett. Rahvas, kes kivil käib, imestab ka selle üle - nii pole veel kunagi olnud. Ojasängis raha ei ole. Kivil käijaid on siiski endiselt palju. Ikka on teenistuse ajal keegi kivi juures ja teised veidi kaugemal ootamas. Vahel on kivi juures ka kaks inimest korraga - ega rohkem ei mahugi. Kivil on küünlaid, paar taskurätikut, välgumihkel, mõni kimp lilli ja raha. Peamiselt vaske, aga ka mõned paberkroonid. Valdur Raudvassar,

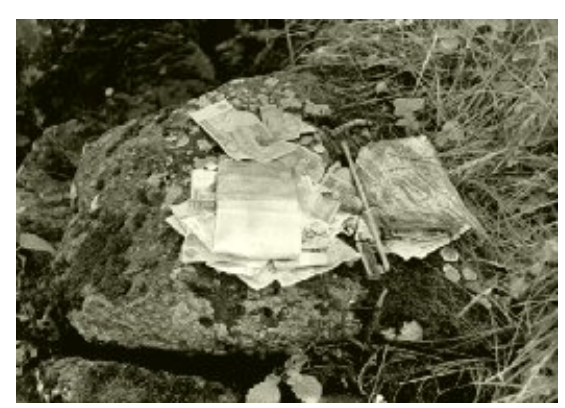
kes jõudis pärale meist varem, räägib, kuidas alguses kirikus rahvast vähe oli, aga pidevalt juurde tuli teenistuse ajal, kuidas kirik täis sai ja laulgi vägevamaks läks. Üks tädi võtab jalast kinga ja paneb jala kivile. Käin surnuaial.

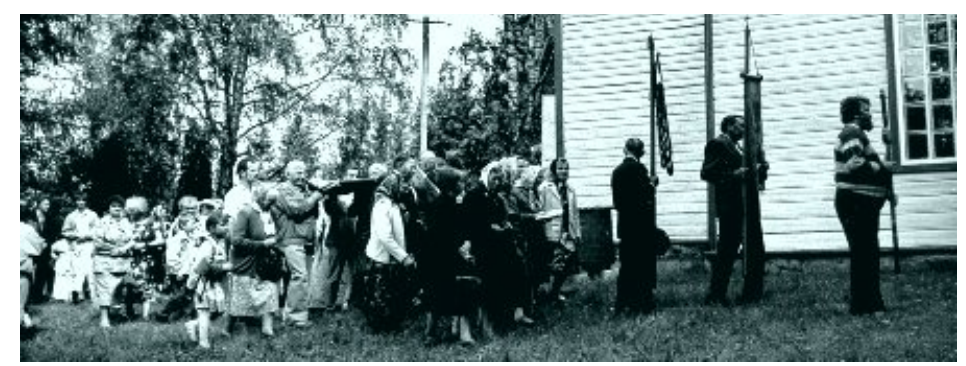

Siis hakkab kirikukell lööma, algab ristikäik. Teenistus on läbi saanud juba umbes kell pool kaksteist! Kolme aasta eest kestis üheni. Teed mööda sõidab auto, täis purjus teismelisi poisse, kes karjuvad ja lasevad signaali. 


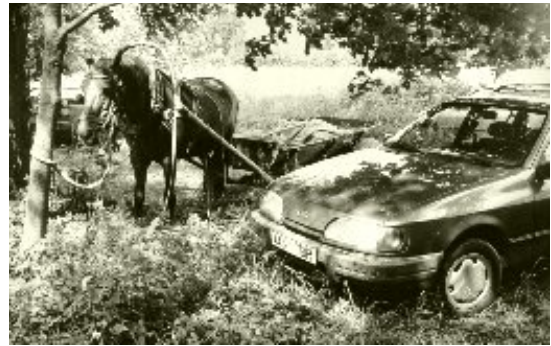

Üldiselt on rahvast nagu rohkemgi kui kolme aasta eest, mil siin käisin. Autosid on umbes kaheksakümne ringis. Surnuaia ääres on ka kaks hobust, ühe kõrval seisab uhke Ford. Teen neist pilti. Lisaks autodele on Meeksis ka kaks suurt bussi soomlastega, kes hämmastavalt viisakad oma olemisega ja püüavad eesti keelt rääkida. Keegi rahva seast kommenteerib, et mis imelikud soomlased - ei olegi tavalised põdrad! Ei torka oma riietuse ega käitumisega kuidagimoodi silma meie tavalistest linnainimestest, ainult keel on teine. Siis selgub, et polegi niisama soomlased - on hoopis karjalased ja Tuglase Seltsi rahvas.

Surnuaial on ka Tea, tema ema, Kai ja väike Ode-Liis.4 Kõigil on kiire. Tuulel. Ja Merikesel. Ja Ahtol. Kõik peavad kuskile minema ja jõudma. Jutt käib ainult selle ümber, kuhu ja kus ja millal peale saada. Siis selgub, et soomlaste buss läheb pool kaks. See võtab nagu aega natuke maha. Olemine ei ole aga õige, üks vastuolu on selles - siin, kus on PÜHA, ei saa olla KIIRE. Kui on Kiire, siis ei ole enam Püha ning nende kahe asja ja olemisviisi vastuseisu tajun siin, Meeksi Jaanipäeval äkitselt väga selgesti. Milleks see kõik, see tulemine ja olemine, kui mõtted on selle ümber, kuidas saada siit minema! Muidugi, teistel on seljataga nädal Petseri-tagust olemist. Ja vist tegelikult minu mõtte pärast Meeksi tulla Tuule ja Merike siin ongi. Aga ikkagi olen distantseerunud: kaugel rahvast, kellel on Püha ja kes omaste haudadel söövad. Ja kaugel ka omadest, kellel on kiire. Ümbruses läheb kõik aga oma ettemääratud rada. Rahvas sööb ja mäletab surnuid. Preester käib haudu pidi, kilekott näpu otsas toitu täis, õnnistab kalmusid ja loeb palvet.

Teen surnuaia veeres lahti kaasas olnud veini, mille ära joome. Tuule küsib minu käest, et kas tal on õigus, kui talle tundub, et kõige lähema haua peal olev tädi vaatab meie peale halvasti. Mina seda märganud ei ole ja loodan, et Tuulel ei ole ehk õigus. Siis teised lähevad bussile, Ahto räägib veel Kuksina kirmaskist, kuhu loodab jõuda. Istun üksinda natuke surnuaia veeres. Siis tõusen ja hakkan minema - ei ole ka minu koht siin.

Lähen veel kivile. Rahva käimine kivil lõppes koos teenistusega. Nüüd on kivi ümbruses ja teel parv poisikesi, nii nelja-viie-aastaseid. Kivi juures on üks vana vene naine, ikka rätikuga nagu kõik vanad, ja umbes kolmekümnene eesti/setu mees. Naine mainitseb poisikesi, et kivilt ei tohi asju ära võtta - et inimesed on need oma haiguste pärast siia toonud. Ja räägib eestlasele sellest, et tuleb paluda Jumalat. Sellest, et Maa on meie ema, kes kõike sünnitab ja kasvatab. Sellest, et kui paluda, siis Jumal annab meile andeks. Mees ütleb, kanges vene keeles: A ja tak mnogo ploho delal!- mõte selles, et mis siin enam andeks paluda. Naine ütleb, et paluda tuleb ikka. Põlvitab maha püha kivi juures ja tõstab kokkupandud käed taeva poole: kui paluda, siis Jumal annab andeks. Ainult paluda tuleb kõigest südamest! Mees läheb ära. Minnes räägib poisikestele eesti keeles kõrvalolevalt sellest palumise õpetusest: tundub, nagu tahaks ta end sellest pealepandud ebameeldivast koormast vabaks rääkida.

Kuiva ojasängi põhja on vahepeal tekkinud mõned vasksendid. Lähen üle purde kivi juurde. Taskurätid, välgumihkel ja paberraha on kadunud. Ka metallraha näib olevat vähem kui seda oli enne - kuigi tema hulk võiks vahepeal hoopis kasvanud olla. Kivi ligidal passib üks viie-kuueaastane poisike. Vist ootab minu minekut. Mõtlen, kas minna temaga rääkima. Aga ei lähe: võibolla on ta siin juhuslikult niisama ja miks minna süüdistama, kui ma ju ei tea, et ka tema võtnud on. Lähen maanteele, kuigi sisetunne ütleb, et ka tema on üks neist võtjatest. Kivi poole tuleb teed mööda üks väike poiss ja limpsib jäätist. Teisel pool surnuaeda on lavka. Kolme aasta eest selliseid poisikesi kivi juures veel ei olnud. 
Lahkun Meeksist ja jalutan teeviida järgi Viitkale, Võru-Luhamaa maantee poole. Tee põhjaküljel on metsas maasikaid. Söön neid, vähemalt ei ole kiire. Minust sõidavad mööda autod surnuaialt tulijatega. Kui jõuan Luhamaa teele ligidale, vurab mööda üks vanker. Vankris on kaks naist: üks rätiga vana ja teine keskealine, ning kaks last. Vana naine laulab heleda häälega, hobune laseb traavi ja jätab tee peale märja liiva sisse jälgi. See on päris. Nad mööduvad minust ja kaovad käänaku taha.

Suure tee peal hakkan hääletama. Peagi saan otse Kanepisse. Sääl ostan putkast topsi mahla ja küsin müüjalt, ega Tartu poole midagi minemas ei ole - sõiduplaani järgi ei lähe enne üheksat miskit. Müüja ütleb, et kohe on Tartusse buss minemas ja minuti pärast ongi see päral. Istun sisse ja sõidan.

\section{Meeksi jaanipäev 1997}

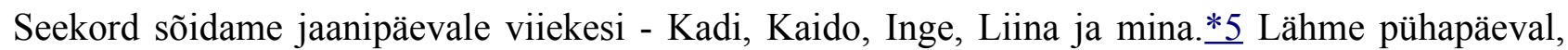
kuuendal juulil. Hommikul lahkumine Viljandist, Tartus enne sõitu veel kiire käik turule - hea, kui söök ja jook omal kaasas on. Siis Võru bussijaam, kus busse on jälle hõredamaks jäänud. Plaani järgi läheb esimene buss Misso suunas alles pool kaheksa. Nii me siis murul ootame, seltsiliseks üks noor vares bussipeatuse sildil, sõbralik kollinäoline pika karvaga koer ja sipelgad rohukõrte vahel.

Tegelikult saame hoopis teise, plaanis mittekajastuva veerand kaheksa väljuva bussi pääle. Bussijuht, lahke Võrumaa mees, annab nõu, kus oleks õigem maha minna. Väljume Illis ja lähme edasi Vahtseliina. Siis väike arupidamine teeristis, aga et aeg juba hiline, asume linnusesse mineku asemel öömaja otsima. Lähme mööda teed Meeksi poole. Tahaksin näha veel vana Annat, keda mullu 13. mail kohtasin ja ka lindistasin. Anna rääkis ilusa loo sellest, kuidas Püha Maarja ei lasknud mehel oma naist ära tappa, vaid läks ise asemele. Suvine maastik on aga jala käies hoopis teistsugune, kui kevadel autoaknast enam kui aasta tagasi. Nii ongi hää võimalus küsida teed külamehelt, kes Meeksi poolt vastu tuleb. Mees juhatab lahkelt, minekul annab kätt. Käsi on väga soe ja tugev.

Kui pärale jõuame, seisab lauda ees suur heinakoorem. Peremees, tugev ligi 55-aastane mees, on õues ja vaatab võõraid. Kui ütlen, et mullu kevadel siin käisime ja et tahaksin ta ema näha, siis näib nagu midagi meelde tulevat. Küsin, ega koorma sissepanekul abi vaja ole. Mees ei ütle midagi. Siis pärib, kas meil öömaja olemas. Ütlen, et ei ole, et alles vaatame ringi, kuhu võiks jääda. Peremees näitab kätte koha heinaküünis, kuhu oma kotid maha seame. Seejärel juhatab mind Anna juurde, aga ütleb, et ema on väga viletsaks jäänud. Nii ongi. Tuba on hämar ja Anna, kes lebab akna all voodil, paistab selles pimedas õhtuvalguses muldvanana; ta käed ja nägu tunduvad värvilt lausa mustad õhtuses varju ja valguse mängus. Juba eelmisel kevadel lootis ta, et käo ühekordne kukkumine minekut tähendab. Ütlen, et tulime Jaanipäevale. Anna vastab, et täna oli juba kella viie ajal kirik. Vahepeal ei ole palju aastaid jaanilaupäeval teenistust peetud, nüüd oli üle pika aja esimene. Anna on väsinud ja pikalt juttu ei räägi. Lähen ära välja.

Pakume end siis jätkuvalt heina kallale. Peremees on läinud traktoriga kapsaid kündma. Perenaine, tüsedam ja rõõmsameelse olemisega, ei taha meid algul viisakuse pärast heina ligi lasta - küll nad ise saavad hakkama! Meil ju Tartust pikk tee selja taga - istuge ja puhake! Kolmas pereliige on tütar, valgetverd ja väga särtsakas neiu. Midagi ühist on tema näojoontes vana vanaema omadega Anna võis noorena vist samasugune välja näha. Tütar on õppinud Väimelas ja nüüd aasta Norras olnud - ikka põllumajanduse peal. Olemiselt lahke, aval ja rõõmus, on ta sõnades meie töölepakkumisele veelgi vastalisem kui vanemad. Ei otsi Ingele esialgu tööpüksegi ja toob need alles siis, kui ta juba hulk aega paljasääri heina sees tegutsenud on. Heina on kaks keskmist traktorikoormat ja saame nendega päris ladusalt hakkama - viiekesi läheb ruttu. 
Talu taga on Meeksi oja kergelt üles paisutatud - hää piima hoida. Sääl, uskumatult soojas ojavees heinatolmu ja higi maha pesemegi, nii nagu vanasti. Siis kutsutakse majja, kus köögis on viiele laud kaetud. On leiba-saia, piima, morssi, värsket salatit ja pasteedilaadset sööki, mille nimeks peensült, nagu selgub. Pärast sööki asume minekule Meeksi - sääl on täna jaanituli.

Lähme mööda teed õhtuhämaras. Vili on suur ja kahel põllul häälitseb otse tee ligiduses rukkirääk. Meeksi poole sõidab ka autosid. Tee ääres vasakul hingitseb kustuv lõke ja sisemaa poolt paistab teinegi. Kuigi maantee läheb läbi Võrumaa, mäletatakse ka siin vana Jaanipäeva. Meeksis teeme esimese käigu kivi juurde. Kivi on hämar ja ojas vesi kõrge. Teised ei ole siin varem käinud.

Mäel on rahvast palju - vähemalt poolteistsada inimest. Näib, et neid on olnud rohkemgi, sest vanemad inimesed sätivad end minekule. Aeg on ka juba hiline - ligikaudu kesköö ju. Mäetagusel platsil on ligi paarkümmend autot. Tule juurde on toodud pingid ja mingi bänd mängib päris talutavalt hästi rahvalikke laule. Ei mingeid pileteid siiski. Kui pillimeestel kõri kuivaks jääb - nii mikrofoni öeldaksegi - tuleb ka lindimuusikat. Otsime omale kohta, kus istuda ja veinid välja võtta. Kõrge rüäpõllu ääres, kuhu end alguses seame, ründavad meid aga sääsed ja nii asume vabale pingile tule äärde esiritta. Moosekandid õhutavad rahvast tuld lisama ja hoogus poisid asuvadki jämedaid ümaraid puid lõkkesse pilduma. Sädemed lendavad ligi paarikümne meetri kõrgusele musta öötaevasse nagu tillukesed puugid. Rahvas on niisama ja ajab juttu, nooremad ka tantsivad. Üks vanem pruuni lokkis pääga mees on silmapaistvalt hoos. Tantsib üksinda tule ääres, siis vahepeal nagu paaristantsu põlemata puude hunnikuga. Ütleb, et on Merekülast ja et ta jättis oma naise Maarja koju. Aina lööb tantsu tule ääres, vahepeal istub ka pingile puhkama meie ligidusse. Kadi ütleb pärast, et olevat öelnud, et tüdrukud teda ei pelgaks: Maq olõ õigõ inemine! Siis näeme ka peretütart piduliste seas. On korra ja kaob rahva sekka. Liina, kes korraks tule äärest tahapoole tõmbub, püütakse kinni ja viiakse tantsima.

Oleme natuke väsinud ega jää päris peo lõppu ootama. Jalutame teed mööda tagasi oma küüni läbi sooja öö. Tee jookseb oja Võrumaa poolsel kaldal. Kui koju saame, jõuab õuele auto kahe noormehega. Pakuvad õlut ja soovivad hääd ööd. Selgub, et perepoeg - on Tallinnast sidepataljonist pühadeks koju lastud. Homme õhtul peavad jälle pealinnas tagasi olema.

Hommikul ootab meid taas söögilaud. Nüüd on laual lisaks peensüldile ka kartulisalat ja värskelt praetud soojad kotletid. Lisaks muidugi rammus talupiim. Minek kiriku juurde on lühem kui õhtune. Siiski on maa pikk ja kui pärale jõuame, teenistus juba käib. Kell on ligi pool üksteist. Preester loeb parasjagu evangeeliumi Johannesest - täna on tema päev. Väljas on rahvast esialgu veel hõredalt, aga tasapisi tuleb inimesi juurde. Haudadele tekivad linaga kaetud söögikandikud.

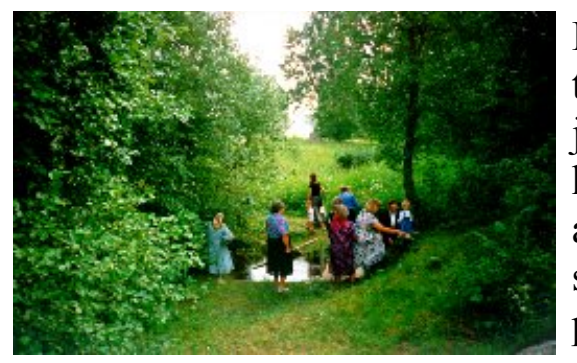

Lähme kivi juurde, oja on vett täis. Eelmisel suvel polnud siin tilkagi. Kiriku poolt viib kivi juurde uus laudpurre, vana sillakese jäänused on sügaval vee all. Vesi on roostepunane ja põhjast helgivad vastu mõned mündid - siiski palju vähem kui 1993. aastal. Seisame kivi juures. Sel aastal on oja äärde tekkinud ka surnuaiapingi moodi pink. Küsin sellel istuvalt venelaselt tikke ja panen kivile vana Teplenkova Mari poolt küünla. Kolmekroonise, nii nagu ta palus. Kivipealnegi on tänavu märksa hõredam kui mullu või nelja aasta eest. Ainult raha on siin - paberist ühekroonised, mida hoiab tuule eest rusikasuurune kivi - ja kollane vahaküünal. Münte on väga vähe. 
Pingil istub üks 60-70 vahel naine, kellelt prooviks küsin midagi Jaanikivi kohta. Naine, kleidiga ja ilma pearätita, halli peaga, - kuigi seto päritolu Kiislova külast - osutub luterlaseks. Nagu selgub, ühe kirikuõpetaja ema. On kuidagi hoopis teistmoodi kui setod - mingil moel distantsis tänase pühaga, kuigi seda vaatama tulnud, ja ratsionaalse olemisega. Ise ütleb ka, et tuli siia seda setode püha vaatama, ja lisab nagu enda üle nalja heites, et ei ole sellest setode asjast ikka päris lahti. On väga jutukas ja raske on leida pausi, et lõpetada seda monoloogi.

Siis tuleb hetk ja lähme tagasi kiriku juurde. Väljas on kraaniga anum ristiveega, nõu peal palju paberist krooniseid. Võtame vett ja vaatame niisama surnuaial ringi. Ojal ja kivil käijate rivi on vahel päris tihe, vahel

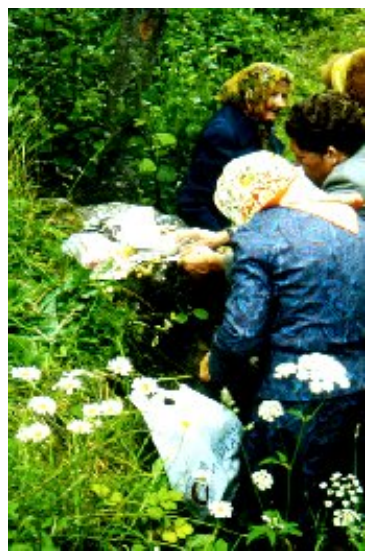
hõredam. Kui luterlasest tädi on oja juurest ära tulnud, lähme tagasi. On venelasi ja setosid. Istutakse kivil, pannakse haige koht kivi vastu. Kui kivi ümbrus tühjaks jääb, teeme seda meiegi. Pesen ojaveega Viljandist pärit sääsehammustusi. Kummaline, aga sügelus kaob. Pärastiseks jäävad alles vaid need hammustused, mis tulid peale pesemist. Kuigi olen arvanud, et nüüdseks on kivile tekkinud lisaks rahale ka muid asju, on raha hulk hoopis vähenenud - kivil on vaid mõned paberkroonid.

Siis üks episood: kivi juurde tuleb 14-15-aastane lühikeste pükstega vene poiss, vaatab pika pilguga kivil olevaid rahasid, siis mind, kes ma kivile toetan. Võtab rinnataskust kroonise, paneb selle kivile, lööb rusikasuuruse kivi hookalt tuuleraskuseks peale ja läheb. Selleks korraks. Võrreldes ajaga neli aastat tagasi ja ka mullusega on kivil käijaid nagu vähem - eelmistest käikudest sellist pausi, kus kivil poleks kedagi, kirikus oleva teenistuse ajast nagu ei mäletagi. Nüüd on ajal, mil kivi meie vaateväljas, tema ümbrus aga üsnagi mitmel korral tühi ja see seletab ka raha kiiret kadumist.

Keskpäeva paiku hakkab lööma kell ja rahvas koguneb kirikust välja ristikäigule. Lahkume meiegi kivi juurest ja lähme üle oja, orunõlvast üles. Lähme Kadiga ka ristikäigulisteks - mina vaid poolenisti, tänu oma fotoaparaadile. Kui suurt pühast sisse viiakse, käib rahvas selle alt läbi. Tahtjaid oleks ilmselt rohkem kui läbipääsenuid, aga inimvool katkeb, sest kandjad viivad pühase ära kirikusse. Siis vaatame veel surnuaial ringi. Rahvast on nüüd palju, kõik pidulikult riides. Väga suur kontrast eilse õhtuga, kus riietuseks olid valdavalt dressid ja T-särgid. Aga seto rõivaid ei ole kellelgi.

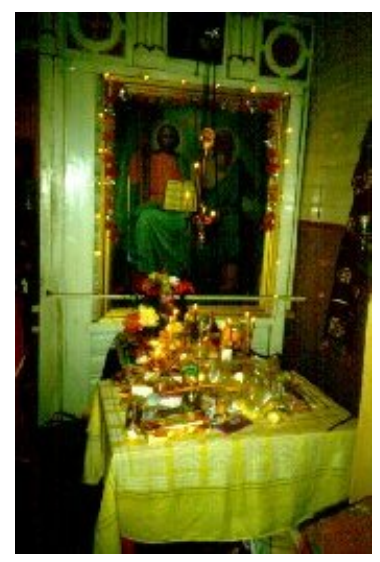

Autosid on palju ja igasuguseid - uhkemaid ja lihtsamaid. On ka üks hobune. Ilus väike karvane loom, uhked vanaaegsed hõbedaste naastudega päitsed pääs, sööb surnuaia taga rohtu. Lähme teeme Kadi ja Kaidoga tiiru haudadele. Inge ja Liina jäävad istuma - Liina ütleb, et tema ei tule. Vaatame siis ringi - lähemaid tuttavaid siin ju pole ja ka oma võõrustajad surnuaial silma ei hakka, kuigi neid siin vahepeal kohtasime. Astume veel korraks ka kirikusse, kus preester õnnistab kutjalauale toodud sööke. Kirikus on vanu naisi nii paarikümne ringis. Kui õnnistamine läbi, tullakse välja põhjapoolsest külguksest. Maarja altari ees on väike lauake, mil ristiga kirikuleivad ja lehed mälestatavate nimedega. Tahan lauast pilti teha, aga siis hakkavad naised välja tulema ja leibasid ära võtma. Kui liikumine lõpeb, on leibu lauale jäänud vähe. Siis on algamas ühe väikese lapse ristimine. Pere õiendab kirikus. Keegi ruttab läbi surnuaia, veepang käes. Tuleb aga ülevalt küla poolt, mitte ojalt.

Kui hakkame tagasi jõudma sinna, kuhu Inge ja Liina jätsime, märkame neid hoopis ühel kaetud haual pingi pääl istumas. Viipavad meile ja astume sinnapoole. Üks ülikonnas ja säravvalge särgiga 
noormees kutsub meid sisse. Annab värava kohal kätt ja ütleb, et tema nimi on Leho. Pakub süüa ja ütleb, et ise võtaksime - et ärgu me häbenegu! Seda kordab pärast veel mitu korda. Haua peal on ilusad söögid nagu ikka: koogid, küpsised, võileivad, kommid ja suur maasikatort. Leho ütleb, et see on tema ema haud. Ema suri sünnitamisel ja oli 36 aastat vana. Leho on ise 28, elab praegu hoopis Pärnumaal.

Surnuaiapingil istub aga ka üks noor valgepäine naine. On kuidagi väga kinnine ja reserveeritud. Kogu tema olemine väljendab sunnitud olekut ja selget üleolekutunnet surnuaial toimuva suhtes. Eestlane vist.

Siis tuleb juhtum. Üks tumedas ülikonnas purjus mees - silmapaistev erand surnuaialiste seas - kakerdab pingi poole, millele säetud söögid, komistab ja kukub. Söögid libisevad taldrikutelt maha, osalt hauale. On segadus. Tüdrukud asuvad asju maast taldrikutele tagasi tõstma. Mingi ebakindlusetunne on selles: eelmisel aastal, kui Obinitsas paasapäeval sööki maha libises, öeldi ju, et seda enam üles ei võeta. Siin aga ei öelda midagi ja tagasikorjatud asjad tunduvad siiski õigemad kui segaminipaisatud hauapealne. Siiski paistab, et neid sööke, mis haual olnud, enam ei sööda. Võtame vaid maasikatorti, mis katastroofist õnnelikult pääsenud. Mees, vist Ossi on ta nimi, räägib peaaegu artikuleerimata kõnet, pakub juua ja tahab, et temaga juuakse. Praalib, et tal on automaat ja kuulipilduja ning

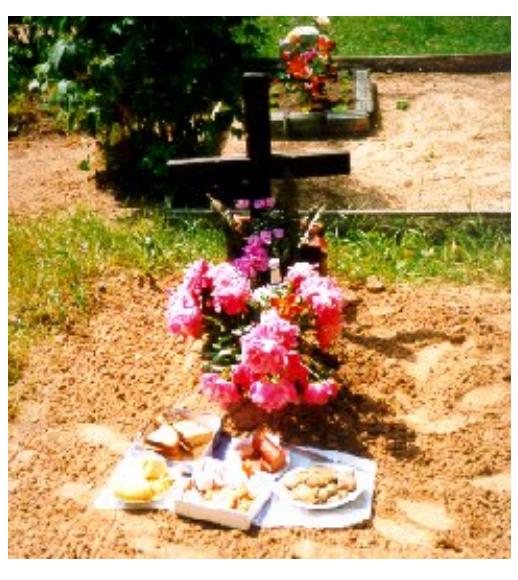
pakub neid müüa. Maani täis ja vastiku olemisega on ta, ülbelt agressiivne. Purjus ja ärplevana jäi ta silma juba eilsel jaanitulel, kuigi siis temaga lähemat kokkupuutumist polnud. Kui istun ta kõrval pingil ja pitsi valamiseks käes hoian, võtab ta selle mu käest ära, vaatab otsa, joob ise ja annab alles siis mulle. Olen samalaadset olukorda ka varem kogenud - kevadisel jüripäeval Värskas Kolja juures, kus üks tema noorematest sugulastest viinaringi enne omade keskel ära tegi ja alles siis minule pakkus. Tundub, et mitte juhus, vaid üks viis võõraste paikapanekuks. Küsib minult, keda siit Meeksist tunnen. Kui ütlen ühe perekonnanime, lausub ta mind taas paika pannes: Halv inemine! Ebameeldiv elamus on see mees, üks Setomaa kontrastidest.

Meie oleme siiski siia kutsutud - Leho ema hauale. Leho on täiesti kaine - on tüdrukutele rääkinud, et olla eile õhtul palju joonud ja et nüüd on selle pärast väga piinlik. Enne minekut teen teistest koos Lehoga pilti - tema on hea. Võtan ka aadressi. Siis on surnuaial oleku aeg täis - liiga pikalt siin enam olla ei taha. Enne minekut tuleb Ilmar Vananurm ja annab kaks viimast numbrit Setomaa lehte. Kodus loen sellest, et kui president Lennart Meri Obinitsas käis, kinkis Sillaotsa Liidi talle Obinitsa muuseumis kirjadega kindad. President tegi vastukingi - kinkis needsamad kindad Obinitsa muuseumile tagasi.

Jälle minek mööda teed. On hää, et kellelgi ei ole kiire. Selles mõttes on läinud hästi, kohe väga. Lähme vaatama mõisalauta, millesse Meeksi mõisa valitseja laskis müürida Jaanikivi tükid. Tuleb peremees, Võrumaa talunik.

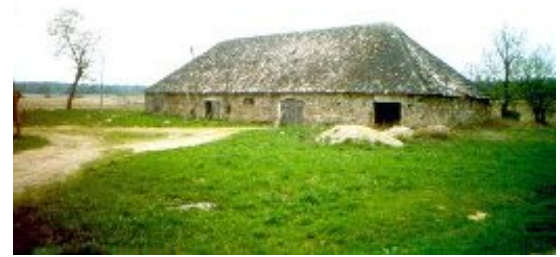
Ütleb, et teise samalaadse maakivist abihoone uksel on aastaarv, vist 1867 . Ju võiks see uhke kivilautki sama vana olla. Lauda katus püsib viimaseid aastaid. Omanik on Saksamaal ja mingit parandamislootust ei ole. Siis jälle maanteele. Meist kihutavad mööda Jaanipäevalt lahkuvad autod, keerutades üles tolmupilvi. Taas ilmneb kahe makonna piirikontrast: talu juures, millest möödume, sätivad mehed looreha. See talu ja tee on Võrumaal, Setomaal aga täna tööd ei tehta. Setomaal on püha. Ka veel siis, kui oleme juba öömajatalu teeotsa ligidal, püsib kaugel surnuaia kohal helisev häältepilv, nagu oleksid inimestel lindude hääled. 
Taas ületame oja ja Setomaa piiri ning jõuame tallu. Peremees on piduse olemisega, pere on matuste päält juba enne meid tagasi jõudnud. Oleme heinaküüni ees ja ajame juttu. Peremees küsib, kas tänaseks ka öömaja vaja on. Ütlen, et ei - et oleme minekule sättimas. Peremees kostab, et eks nii parem olegi või midagi sarnast. Siis räägib pikalt oma muredest. Esimene mure on, et poeg, kes sõjaväes, ei ole pilku visanud ühelegi meie kolmest tüdrukust. Kuigi jutt näib lõõpimisena, on selle taga ilmsesti tõsine mure: mis saab talust? Tütar kavatseb jätkata õppimist Tartus, on oma valikud ilmselt juba teinud. Samas tunnistab peremees, et eks temagi võttis naise hilja - alles 31-aastaselt. Mees on kuri valitsuse ja riigi peale: vägisi suretavad põllumeest! Ütleb, et kuigi ta ei tea, kes mina selline olen - ülikool ju ikka linnas! -, ei karda ta tunnistada seda, et on riigi ja valitsuse vastane. Siis lisab veel nukralt: Ma lähessi küll Toompea vastu, a kust ma selle sõaväe kokko korja? Hiljuti on piima kokkuostuhinda jälle suveks alla lastud - nagu lehmadega suvel vähem vaeva oleks kui muul ajal! Piim on aga selle talu ainus rahaallikas. Talus on neli lehma ja headel aegadel annavad nad 90-95 liitrit piima, rasvaprotsent on 4,8. Mees on pahane nii kokkuostuhindade kui petmise peale - piima müüakse edasi palju kallimalt, aga kõigest 2,5\% rasvasisaldusega - poole panevad vett juurde! Mingeid töökohti, kust võiks lisaraha teenida, ümbruses pärast majandi lagunemist ei ole. Küsib mitmeid ja mitmeid kordi, kas me nägime või õigemini kuulsime, kui vara ta hommikul tööle läks, ja kas märkasime, mis ajal ta õhtul traktoriga kapsapõllult tuli. Nii on see iga päev, päevast päeva. Selge, miks 55-aastane mees näeb välja nagu seitsmekümnene. Küsin, kas ei võiks kõne alla tulla piimaühistu tegemine talude peale, et kümnekonna talu piim koos linna müügile viia - turul maksab korralik maapiim ju 4-5 krooni liiter. Vastus on resoluutne: Ei tulõ kõnõ allaq! Kui küsin, miks, saan vastuseks loo seitsmest hiina targast: Tulid targad kokku ja pidid hakkama viina jooma. Igaüks pidi tooma pudeli viina, mis pidi kallatama ühisesse nõusse. Kui jooma hakati, selgus, et nõus on puhas vesi. On selge, et siin on põlvest põlve õpitud ise hakkama saama. Jutu resümee on: Rikkaks ma ei saa, aga nälga ka ei jää!

Talu elamu on uus, silikaatplokkidest. Küüni taga on ka vana maja - ilmselt juba sajakonna aasta eest ehitatud ehe ristpalkhoone. Olen juba eelmisel õhtul avaldanud soovi seda ka seestpoolt näha vana ahigi pidavat veel alles olema. Viin nüüd jutu uuesti maja peale. Kui eile oli vastus põiklevam - sääl on kõik nii segamini! - siis nüüd öeldakse otse ära, miks meid sinna sisse ei lasta: majas on väikene töökoda, iseendale teed - kust sa muidu saad! Kui lased võõrad sisse - mine tea, äkki tulevad pärast vargad. Ütlen, et tahaksin ka vanale Annale hääd aega soovida. Peremees vastab: ̈̈ra emat sega, ema on väsinud. Lase ta puhkab! Lisab, et emale oli väga tähtis, et täna Meeksis sai käia. Alles nüüd saan aru, et see oranzhi ja kollase kirjus riietuses naine, keda nägin istumas ühel haual, oligi vana Anna.

Varsti kutsutakse meid kööki, kus lisaks kotlettidele ja kartulisalatile ootamas ka praetud sealiha. Heidan tulles ukse vahelt pilgu ettetuppa, kus Anna voodil selili puhkab, kaks kätt rinnal. Ma ei näe tema nägu, pea ja rinna lõikab ära pooleldi lahti olev uks. Peremees käib küsimas, kas piima juurde tahame. Et talle häädmeelt teha, palun klaasi lisaks. Vastukäiguks on terve kann, mis tuleb tingimusteta tühjaks juua. Kui tekib tasaseid vastuväiteid, et kõhud juba väga täis, saame vastuseks: Kas teile mu piim sis ei maitse? ja Ega mul sellest piimatsilgast kahju ei olõ! Pääle sööki asume minekule. Ütleme aitäh ja lähme. Peremees saadab meid maja otsani, käepigistus on korralik. Taas üks kogemus ettevaatlikust ja põlvest põlve edasi antud tarkusest: päriselt usaldada võid ainult iseennast.

Siis lähme Vahtseliina. Nüüd on Inge ja Liina aeg täis ja nad peavad minema bussi peale. Linnus jäigi neil nägemata - said ainult kaugelt valendavad-punetavad tornid. Siiski ei olnud neil kiire. Aitäh selle eest! Meie Kadi ja Kaidoga lähme varemetesse. Istume peatorni müüriserval. Selles tornis oli kunagi lossikabel, milles asus keskajal linnusesse palverändureid toonud Püha Rist. Aeg voolab või on. Varemetes käib üks perekond võõramaalasi. Arvame, et vist ungarlased. Käime ka 
kõrget ja lagunevat treppi mööda all Piusa ääres. Kui üles tuleme, on ungarlased läinud ja Kadi saab minna oma torni, kus veelgi istume.

Õhtuks on kava jõuda Meremäe mäele - sinna, kust selgete ilmadega näeb Pihkva järve. Asume teele. Juba linnuses on ilmnenud, et üks Kadi kingadest on käimisega katki läinud. Tartus olen enne tulekut Kristilt küsinud, kus on tema vanaema talu - ei ole paha, kui mingid varuvariandid igaks juhuks olemas on. Nüüd keeramegi sinna suurelt maanteelt kõrvale sisse, et küsida nõela ja niiti.

Talu juures tehakse heina. Esimene reaktsioon võõrastesse matkajatesse on imestunud ja äraootav, aga kui küsin ühe sõbra vanaema, on olukord lahendatud. Otsitakse nõel ja niit ning tuuakse joogiks hääd heinateokalja - piimast on kõhtu hakanud jälle ruumi tekkima. Pakume end ka heina lõpetama, aga töö on juba tehtud ning meie abi vaja ei lähe. Seni, kui Kadi nõelub osavasti oma rihmikut, katsun natuke juttu ajada. Setomaa küladest ei tea vanaema midagi - ei ole sinnapoole kunagi asja olnud. Kui küsin tema tütrelt, saan vastuseks: Kes mind sinna laseb! Piir kahe maakonna vahel on tõesti väga terav ja Võrumaa on puhtalt orienteeritud sisemaa poole - Setomaale pole lihtsalt kellelgi asja. Kui vanaemalt küsin, kas siin Võrumaal ka vana jaanipäeva tähistatakse, kuulen, et see on setode komme - nendel on palju igasuguseid pühi, aga siin Võrumaal ollakse luterlased. Küsin, kas siis ka vanasti siinpool piiri vana jaanipäeva ei peetud. Saan teada, et vana jaanituld tehti kuni Nõukogude ajani. Uus aeg lõi vanad kombed aga kohe segamini ja kõik kadus. Pärime veel Võru- ja Setomaa piiri kohta ja saame juhatust, mille järgi Piirimäe ära tunneme.

Jälle teele. Maanteele on pandud uus asfalt, kaugemal käib tee pindamine. Asfalti pidi vuravad suured kollased masinad. Eesti riik loob piiriäärset infrastruktuuri. Siis jälle Võru- ja Setomaa piir, tähiseks teeäärne suur, juba täiesti kuivanud mänd. Maa Kalatsovva on lühem kui esialgu ootasin. Astume sisse talumees Ennu juurde, kelle juures 1993. aastal alet tegime. Enn ei tunne mind algul ära ega ka mina teda, aga kui toimunut meenutan, tuleb kohe tuttav ette. Tuletab meelde seda võimsat meestelaulu, mis oli ta saunas siis, kui pärast aletamist kuuekilost suitsetatud karpkala sõime, ja küsib, mis poistest saanud on. Kuuleme ja näeme, et üldine olukord pole kiita: talu seis on täpselt sama, nagu neli aastat tagasi - midagi ei ole edasi läinud. Ja alemaa kohal pole viljapõld, vaid hein. Paigalseisu põhjuseks on piir: Vene turg, kuhu Setomaa põllumajandus aastasadu orienteeritud, on topelttolli tõttu põllumajandussaaduste müügiks suletud. Kui sinna müüa, tähendaks see kahjumiga tootmist. Eesti sisemaa on aga kaugel ja siinne toodang pole sisemaa heade põllumaapiirkondade omaga konkurentsivõimeline. Kui siin loetakse 20 tsentnerit hektarilt heaks saagiks, siis saadakse Järvas ja Virus sama tööga 40. Kui küsin, mis on Setomaa jaoks praegu kõige tähtsam, on vastus täiesti ühene: vaba kauplemine Venemaaga - see lahendab kõik probleemid. Et talu elus hoida, peavad Enn ja Sirje Meremäel kohvikut. See asub kahekordses uues majas, teisel korrusel. Tegelevad ka lavkamüügiga: olid eile olnud Meeksis ja täna õhtul peavad minema Kuksinasse, kus kirmask tulekul. Ei taha minna, aga peab, ütleb Sirje. Ega me tegelikult siia öömaja paluma tulnudki - mõtlesime öö hoopis lageda taeva all Meremäe lael mööda saata - ja seda ka Ennule ütleme. Siiski teeb Enn sauna lahti ja jätab selle meile. Igaks juhuks, varuvariandiks.

Olen tulnud siia Kalatsovva ka väikese tagamõttega - et saada teadmist kalme kohta, millest vana Sari Aleks on Meremäe uuele raamatukoguhoidjale Tiinale rääkinud. Sirje käibki naabertalus maad kuulamas, kas Aleks meid jutule võtab. Tuleb tagasi ja ütleb, et Aleks on hääs tujus - öelnud, et tal on iga päev kõnetunnid. Lähme siis. Perenaine kutsub meid lahkesti sisse ja pakub pühadesaiu ja tükkideks lõigatud pitsat, mis aga täis kõhu tõttu söömata jäävad.

Vana Aleks, 85-aastane, on selgelt rõõmsameelne - taustaks ilmselt ka tänane jaanipäev. Kukub lahkelt pajatama oma eluloost ja muudestki asjadest, mida jõudumööda konspekteerin. Lõpuks jõuame ka kalmeni. Perenaine räägib avameelselt vahele, et ei taha, et tullakse nende kalmeid kaevama, ja lisab ka põhjenduse: asjad kaevatakse maa seest välja, viiakse kuskile minema ja siis 
kohalikud inimesed ei teagi, mis siin on või oli. Mina olen sellise põhjenduse üle sisimas pettunud. Lootsin ju kuulda seda, et inimesed ei taha, et võõrad surnuid üles kaevama tulevad, aga olin kohtunud hoopis teistsuguse, palju uuemaaegse loogikaga. Mis sääl teha - haridus muudab palju nii väärtushinnanguis kui mõtteviisis.

Ka Aleks on oma vanusele vaatamata uue aja inimene - selge eestiaegne põllumees. Vanadest asjadest räägib kui ebausust ja otsib asjadele ratsionaalseid seletusi. Samas tuleb jutu sekka ka üks vana ja võimsam asi. Aleks räägib, et Mokras, kus ta sündinud ja elanud 16. eluaastani, oli üks nõid teinud sauna nõiaasjanduse: vihtadest ja õlgedest seotu. Rahvas toonud selle nõiduse külatänavale ja põletanud ära. Ja siis tuleb veel üks vana mehe elutarkus aegade kaduvusest: Vana ei tule midagi [tagasi] ja kõik muutub!

Aleks on väga seltsiv ja rõõmsameelne taat. Aina jutustab, nii et pean lahkumiseks otsima ettekäänet, et tahame Meremäelt avanevat vaadet näha. Tegelikult kisubki õhtu juba hämaraks ja nõnda me lähmegi. Meremäe vaatetorn on aga läbi mädanenud, nii et ülesronimisest ei tule miskit välja. Redelipulgad on lihtsalt palkide küljest lahti. Lisaks tõuseb meie liikumise peale kõrge heina seest lendu palju sääski, kes torni juures olemise vägagi lühikeseks muudavad. Taandume maanteele, kus jaanituleplatsil oleva kummalise püramiidse katusega seenekese juures kaasasoleva veini ära joome. Siingi pole sääskedega kitsas. Tagantjärele on hää tänada Ennu, kes meile oma sauna avatuks jättis - ise sõitsid nad Sirjega ära Kuksinasse.

Veedame siis Ennu sauna eesruumis oma seekordset viimast õhtut. Laual ootab meid kann piima, ei tea kust, sest Sirje jutu järgi pole külas ühtegi lehma - moonisai ja kausitäis mett. Jätkame ka võitlust kaasasolevate konservidega. Aeg läheb kuidagi ruttu. Öösel katsume laulda, aga see jääb lühikeseks. Uni ja väsimus suruvad peale.

Hommikul ärkame pool üheksa, ilusasti sisse maganud oma poole kaheksase bussi. Võtame asja ühtviisi rahulikult: kui magasime, siis magasime - mis siis ikka. Hea, et kiiret ei ole ja ega keegi hommikusi toiminguidki tagant sunni. Enne lahkumist koputame Ennu ja Sirje üles ja jätame hüvasti. Enn loodab, et kui järgmine kord tuleme, on heinamaa asemel viljapõld.

Nüüd asume teele ja kõnnime mööda maanteed tagasi Vahtseliina poole. Teel mürisevad ikka suured kollased killustikuautod. Maa õitseb aga oma suvist õitsemist ja teeperved on täis lillesid. Käes on suvehari. Siis tuleb hääd kätt üks heinamaa, ilmselt söötis põld, kus paistab õitsemas noort naistepuna. Kui seda korjama läheme, leiame maasikaid. On vaikne, aga samas ka mitte, sest ikka sõidab maanteed mööda autosid. Päris teehäälteta aega on vaid viivuti. Lisaks ilmub teisele poole teed talude juurde üks traktor, mis hakkab mürinal tegema mingit põllutööd, sõidab edasi ja tagasi. Siis palun selle maa kaitsjalt vaikust. Imelik, aga lähebki nii. Traktor sõidab veel natuke, lõgiseb paar korda ja jäb seisma. Taas teadmine juhuse, kokkusattumuse ja ettemääratuse piiride ebaselgusest siin Setomaal.

Lähme jälle. Mööda kuivanud Piirimännist, Plessist ja talust, kus Kadi oma kinga parandas. Kadi mõtleb Piusale ja nii lähme alla linnuse taganõlva pidi. Järsk nõlvak ja ürgmetsaks muutunud lossipark. Siis Meeksi oja vesi, mis allikatest siin nii külm, et jalad jäävad kangeks. Kõnnime mööda oja. Kui Piusasse jõuame, läheb soojemaks. On hää käia soojas vees, vastuvoolu mööda kärestikku. Vesi virvendab, liigub ja lakkab olemast vesi. Peatus ühel kolmnurksel kivil ja viimane vein. Kella ühese bussi ootamine silla juures. Kuivavad riided sillakäsipuul. Aeg seisab ja voolab. Hää on.

Siis buss Võrru. Magamine. Maasikad ortodoksi kirikaias. Sõit Tartusse. Koosolemine kuni selle päeva lõpuni. Järgmisel päeval käime Maarjamõisas verd andmas. Kadi mõte. Läks nii, nagu pidigi minema. 
*1 Ergo-Hart Västrik, Mari-Ann Remmel, Riina Vesi, Esta Allas, Andres Vindi ja Margo Rääk.

*2 Aare Hõrn, Meelis Krigul-Tobias, Ahto Raudoja.

*3 Tuule Kann, Merike Metsala, Anzori Barkalaja, kes on äsja tagasi jõudnud Ida-Setomaalt usundipärimust kogumast.

*4 Tea, Koidula ja Kai Vassiljeva, Kai tütar Ode-Liis.

*5 Kadi Grichin, Kaido Tee, Inge Laurik, Liina Paadik - Tartu Ülikooli ajaloo eriala üliõpilased. 